\title{
Banana lectin (BanLec) induces non-specific activation of basophils and mast cells in atopic subjects
}

\author{
${ }^{1}$ Department of Biochemistry and Nutrition, CSIR-Central Food Technological Research Institute (CFTRI), Mysuru, \\ Karnataka, India \\ ${ }^{2}$ Department of Pulmonary Medicine, JSS Medical College, JSS Academy of Higher Education and Research, Mysuru, \\ Karnataka, India \\ ${ }^{3}$ Regional Forensic Science Laboratory, Karnataka Police Academy Campus, Jalpuri, Mysuru, Karnataka, India \\ ${ }^{4}$ Laboratory of Immunomodulation and Inflammation Biology, Department of Studies and Research in Biochemistry, \\ Sahyadri Science College, Kuvempu University, Shivamogga, Karnataka, India
}

\section{KEYWORDS}

atopics; banana lectin; histamine

release; serum IgE; skin prick test

\section{Corresponding author}

Yeldur P. Venkatesh

Department of Biochemistry and Nutrition

CSIR-Central Food Technological Research Institute (CFTRI)

K.R.S. Road, Mysuru 570020

Karnataka State, India

Phone: +91 8212514876

Fax: +918212517233

E-mail: venkatyp@yahoo.com

Doi

10.23822/EurAnnACI.1764-1489.64

\section{Abbreviations}

BanLec, banana lectin; BSA, bovine serum albumin; Con A, concanavalin A; HR, histamine release; OVA, ovalbumin; PBS, phosphate-buffered saline; PECs, peritoneal exudate cells; SPT, skin prick test; Tris-CAM buffer, $10 \mathrm{mM}$ Tris- $\mathrm{HCl}$ buffer, $\mathrm{pH} 7.4$ containing 1 $\mathrm{mM} \mathrm{CaCl}_{2}, 1 \mathrm{mM} \mathrm{MgCl}_{2}$ and $0.03 \%$ BSA.

\begin{abstract}
Summary
Dietary lectins play a major role in the activation of mast cells/basophils by bridging cell surface IgE glycans to release histamine and other mediators. In the present study, the effect of mannose/glucose-specific banana lectin (BanLec) on the activation of mast cells/basophils from non-atopic and atopic subjects has been investigated. BanLec was purified from banana pulp in a yield of $7 \mathrm{mg} / \mathrm{kg}$. Leukocytes isolated from heparinized blood of non-atopiclatopic subjects were used for quantitation of the released histamine. Approximately $28.2 \%$ of the atopics $(n=117)$ was positive by skin prick test (SPT) to purified BanLec (100 $\mathrm{gg} / \mathrm{mL}$ concentration), and all the non-atopics $(n=20)$ were negative. Maximal release of histamine was seen at $2 \mu \mathrm{g}$ of BanLec. In percent histamine release, an increase of $35-40 \%$ is observed in case of atopics $(n=7)$ compared to non-atopics $(n=5)$, and the histamine release from atopic and non-atopic subjects correlates fairly well with the total serum IgE levels $\left(R^{2}=0.817\right)$. BanLec also induces release of histamine (26.7\%) from mast cells present in rat peritoneal exudate cells. BanLec can significantly activate and degranulate mast cells and basophils by cross-linking the trimannosidic core mannose of IgE glycans in atopic population as compared to non-atopic population; the activation is marginal in the case of non-atopics.
\end{abstract}

\section{Introduction}

Lectins are proteins or glycoproteins of plant or animal sources that bind specific carbohydrates and agglutinate cells of various types (1); they are a diverse group of multivalent sugar-binding proteins of non-immune origin and are ubiquitous in all forms of living matter, including bacteria and viruses $(1,2)$. Their characteristic agglutination properties imply possible involvement of the membrane glycoproteins or glycolipids containing specific carbohydrate residues in the interaction with lectins $(2,3)$. Several lectins from plant sources have been well studied and characterized. Concanavalin A (Con A) from jack bean ( $\mathrm{Ca}$ - 
navania ensiformis) has been investigated extensively in terms of the protein structure, saccharide specificity and its interaction with a variety of cells (4); it has been shown to activate basophils and mast cells specifically by binding to the carbohydrates on the Fc portion of cell-bound $\mathrm{IgE}$, resulting in the release of histamine and other biological mediators $(5,6)$. Many dietary lectins have been investigated for their interactions with cells of the immune system (thymocytes, splenocytes, dendritic cells and macrophages) and allergic system (mast cells, basophils and eosinophils) (7).

Bridging of $\mathrm{IgE}$ molecules on the cell surface of mast cells/basophils by an allergen or bivalent antibody against IgE or artificially aggregated IgE is a necessary event for IgE-mediated basophil or mast cell degranulation $(8,9)$. The interaction of lectins with basophils/mast cells $(4,5,10)$ leads to release of histamine and other biological mediators, and thus resembles the response of the interaction of food allergens with mast cells/basophils from allergic subjects $(11,12)$. Allergic reactions caused by the activation of mast cells/basophils by dietary lectins are commonly termed as non-allergic food hypersensitivity (formerly termed as "false food allergy"). Lectins can either interact with carbohydrates on cell-bound $\operatorname{IgE}$ or directly with the carbohydrates of cell surface glycoproteins and glycolipids on basophils and mast cells $(5,10)$; however, the end result is similar to the food allergen-specific IgE interaction seen in food allergy (13). A detailed study showed that potato lectin (Solanum tuberosum agglutinin) induces non-specific activation of mast cells and basophils of atopic subjects, and an excellent correlation was seen between histamine release from the buffy coat and serum total IgE level (14). Therefore, it appeared important to address the role of other common dietary plant lectins in mediating false-food allergic reactions.

Banana is widely consumed all over the globe as a wholesome nutritional fruit containing $75 \%$ moisture, $23 \%$ carbohydrates, $1.1 \%$ protein and $0.33 \%$ fat (wet weight basis) (15). Among the proteins, BanLec is a minor protein present in relatively low amounts: $4 \mathrm{mg}$ lectin/100 g fruit, edible portion $(16,17)$. Banana lectin (BanLec) is a homodimeric plant lectin (subunit molecular weight: $15 \mathrm{kDa}$; isoelectric point: 7.2-7.5) belonging to the jacalin-related lectin family $(16,17)$. BanLec belongs to a subgroup of this family that binds to glucose/mannose, but is unique in recognizing internal $\alpha-1,3$ linkages as well as $\beta-1,3$ linkages at the reducing termini $(18,19)$. The structure of BanLec has a $\beta$-prism I fold, similar to other family members, but differs from them in its mode of sugar binding; the reducing unit of the sugar is inserted into the binding site causing the second saccharide unit to be placed in the opposite orientation compared with the other ligand-bound structures of family members $(20,21)$. BanLec does not agglutinate untreated human or sheep erythrocytes, but agglutinates rabbit erythrocytes, and is known to stimulate T-cell proliferation (22).
The present study is focused on studying the effect of purified BanLec on basophils and mast cells from different atopic subjects. Since lectins are often present in significant amounts in many plant foods $(1,2,7,11,16)$, it appeared interesting to study the interactions of BanLec with mast cells and basophils of atopic and non-atopic subjects, to understand their physiological significance and role in non-allergic food hypersensitivity reactions.

\section{Materials and methods}

Reagents, allergenic extracts and animals

Sephadex G-75, compound 48/80, o-pthalaldehyde (OPT), pectinase, concanavalin (Con A), Favin from Vicia faba (broad bean, fava bean or field bean) and murine anti-human $\operatorname{IgE}$ (monoclonal)-alkaline phosphatase (AP) conjugate were products of Sigma-Aldrich Co., St. Louis, MO, USA. Lysozyme, ovalbumin (OVA) and bovine serum albumin (BSA) were purchased from Bangalore Genei, Bengaluru, India. Flat-bottom 96-well microtiter plates (MICROLON) were bought from Greiner Bio-One GmbH, Frickenhausen, Germany. All other chemicals/reagents used in this study were of analytical grade.

Southern grass pollen mix (no. 1651, Bayer Corp., Spokane, WA, USA) contained pollens from Bermuda, Johnson, Kentucky blue, Orchard, Redtop, sweet Vernal, and timothy grasses; this is referred to as grass pollen mix 1. Grass pollen mix (no. P28, Greer Laboratories, Lenoir, NC, USA) contained pollens from Bermuda, Johnson, Kentucky blue, Orchard, Redtop, Timothy, sweet Vernal meadow, fescue, and perennial rye grasses; this is referred to as grass pollen mix 2 . House dust mite extract $(D$. farinae, 10,000 AU/mL) and weed pollen mix were also products of Greer Laboratories, Lenoir, NC, USA. Skin prick tests (SPT) were performed with grass pollen mix 1, grass pollen mix 2, weed mix and house dust mite extract to classify whether the patient was atopic or non-atopic.

Experiments involving animals have been conducted in accordance with the "International Guiding Principles for Biomedical Research Involving Animals" guidelines recommended by the World Health Organization (WHO) for the use of laboratory animals, after obtaining approval from the Institutional Animal Ethics Committee (IAEC). Adult male Wistar rats (4-week-old) housed in the animal house facility of our institute were used for the preparation of peritoneal exudate cells (PEC) as per standard operating procedures described later.

\section{Identification of atopic and non-atopic subjects}

All procedures involving human subjects were approved by the Institutional Research Ethics Committee (approval number: IHEC-07-04), and were conducted in accordance with the ethi- 
cal standards established in the Declaration of Helsinki of 1946 and its later amendments or comparable ethical standards. Written informed consent was obtained from all atopic (allergic) and non-atopic (normal) subjects before enrollment in this study. The atopic $(\mathrm{n}=117$ of which 57 were males and 60 were females) and non-atopic ( $\mathrm{n}=20$ of which 11 were males and 9 were females) subjects were identified based on case history (allergic subjects are chosen at random who had symptoms of at least one allergic condition such as allergic rhinitis, atopic dermatitis, asthma, food allergy, and allergic conjunctivitis) of the subjects and the results of skin prick test (SPT) of certain common allergenic extracts (grass pollen, weed, house dust mite) and prepared banana extracts. The age of the subjects was in the range of 18 to 60 years with a median of 41 years. Banana extract $(50 \% \mathrm{w} / \mathrm{v})$ prepared from the commonly consumed variety (Musa acuminata) was used for this study.

\section{Eosinophil count, serum IgE and serum/plasma histamine levels}

Eosinophil count was determined using whole blood, and expressed as numbers per $\mu \mathrm{L}$ of blood (23). Murine monoclonal anti-human IgE antibody (murine IgG2a, $\kappa$; hybridoma cell line ATCC HB-121, designation E5BB3IIA2) was purified by hybridoma cell culture supernatant on protein A-agarose; this cell line was obtained from National Centre for Cell Science, Ganeshkhind, Pune, India. Serum total IgE (expressed as IU/ $\mathrm{mL}$, and hereafter referred to as serum IgE) was quantitated by ELISA (24) using this antibody. Following TCA precipitation of serum, histamine was extracted, determined by fluorometry (25), and expressed as $\mathrm{ng} / \mathrm{mL}$ serum.

\section{Preparation of banana extract from banana pulp}

Banana was purchased from the local grocery market; after peeling the skin, the pulp portion $(500 \mathrm{~g})$ was chopped into pieces to prepare $50 \%(\mathrm{w} / \mathrm{v})$ extract in salt solution $(250 \mathrm{mM}$ $\mathrm{NaCl} / 5 \mathrm{mM} \mathrm{MgCl} / 5 \mathrm{mM} \mathrm{MnCl} / 5 \mathrm{mM} \mathrm{CaCl}_{2}$ ) containing $0.5 \%$ pectinase. The extract was stirred for $2 \mathrm{~h}$ and left at 25 ${ }^{\circ} \mathrm{C}$ overnight; later, the extract was filtered through Whatman no. 1 filter paper. The filtrate was concentrated using Amicon ultrafiltration system using a membrane having $3 \mathrm{kDa}$ molecular weight cut-off, and the retentate obtained was extensively dialyzed against $50 \mathrm{mM}$ sodium acetate buffer, $\mathrm{pH} 4$.

\section{Purification of banana lectin (BanLec)}

This was essentially performed as per the method described by Koshte et al. (16); this is an affinity-based purification wherein banana lectin having specificity to glucose/mannose will bind to the dextran matrix of Sephadex G-75, whereas all the other proteins will not bind to the column and elute based on their molecular masses. Banana lectin was isolated from $50 \%(\mathrm{w} / \mathrm{v})$ banana extract on Sephadex G-75. The concentrated, dialyzed sample $(28 \mathrm{~mL})$ was loaded onto Sephadex G-75 column $(2 \times$ $110 \mathrm{~cm}$ ), which was pre-equilibrated with $50 \mathrm{mM}$ sodium acetate buffer, $\mathrm{pH}$ 4.0. After loading the sample, the column was washed with the equilibration buffer until the absorbance has fallen to 0.005 . The bound proteins were then eluted with 50 $\mathrm{mM}$ sodium acetate buffer, $\mathrm{pH} 4$, containing $0.15 \mathrm{M} \mathrm{NaCl}$ and $0.5 \mathrm{M} \mathrm{D}$-glucose. The eluted fractions were pooled and analyzed by SDS-PAGE and hemagglutination assay.

\section{SDS-PAGE (reducing) and hemagglutination assay}

SDS-PAGE (12\%, reducing) was carried out following the standard procedure (26) to assess the purity and relative molecular mass of the purified banana lectin. Hemagglutination activity of the purified lectin was carried out using trypsinized rabbit erythrocyte suspension as described by Burger (27). Briefly, a $2 \%$ suspension of trypsinized rabbit erythrocytes $(0.2 \mathrm{~mL})$ was added to a serially diluted lectin solution, gently mixed and incubated at $37^{\circ} \mathrm{C}$ for $1 \mathrm{~h}$, and the agglutination was visualized. The amount of protein present at the highest dilution represents the minimum quantity of protein necessary for agglutination and is taken as the titer.

\section{Preparation of samples (BanLec and banana extract) for SPT}

Based on protein estimation by Bradford method (28), banana extract and banana lectin were prepared at $2 \mathrm{mg} / \mathrm{mL}$ and 200 $\mu \mathrm{g} / \mathrm{mL}$ in phosphate-buffered saline, respectively. The samples were then diluted 1:1 using glycerol (analytical grade) to obtain banana extract at $1 \mathrm{mg} / \mathrm{mL}$ and BanLec at $100 \mathrm{mg} / \mu \mathrm{L}$ concentration; these samples were used for performing SPT on non-atopic and atopic subjects.

Banana extract $(1 \mathrm{mg} / \mathrm{mL})$ and BanLec $(0.1 \mathrm{mg} / \mathrm{mL})$ was used for SPT; these concentrations were chosen since in many allergological studies, purified allergens (natural or recombinant) have been used in the concentration range of $20 \mu \mathrm{g} / \mathrm{mL}$ to 1 $\mathrm{mg} / \mathrm{mL}$, and most whole food extracts have been used for SPT at a maximum concentration of $10 \mathrm{mg} / \mathrm{mL}$. Glycerinated-PBS and histamine base (at $1 \mathrm{mg} / \mathrm{mL}$ ) were used as negative and positive reference standards. SPT was carried out as per the described protocol (29). After $20 \mathrm{~min}$, the wheal and flare diameters were measured; a wheal diameter of $3 \mathrm{~mm}$ greater than that of the negative control was considered as positive.

\section{ELISA for detection of BanLec-specific IgE}

BanLec-specific IgE was detected by indirect ELISA (24). Briefly, microtiter wells were coated with $10 \mu \mathrm{g}$ of BanLec at $\mathrm{pH} 9.6$ at $4^{\circ} \mathrm{C}$ overnight. After the blocking step, the wells were incubated with 
subjects' sera at 1:3 dilution in PBS containing 1\% BSA $/ 0.05 \%$ Tween-20 at $4^{\circ} \mathrm{C}$ overnight. Next, incubation was done with murine monoclonal anti-human IgE-AP conjugate (1:1500 dilution) at $37^{\circ} \mathrm{C}$ for $2 \mathrm{~h}$, followed by color development.

\section{Isolation of leukocytes containing basophils}

The buffy coat (leukocyte layer containing basophils) was isolated from $10 \mathrm{~mL}$ of venous blood drawn from non-atopic $(n=10)$ or atopic $(n=20)$ subjects as described $(30)$ using $6 \%$ dextran T-700 gradient. The buffy coat was washed 4-5 times with isotonic PBS and resuspended in Tris-CAM buffer $(10 \mathrm{mM}$ Tris- $\mathrm{HCl}$ buffer, $\mathrm{pH} 7.4$ containing $1 \mathrm{mM} \mathrm{CaCl}_{2}, 1 \mathrm{mM} \mathrm{MgCl}_{2}$ and $0.03 \%$ BSA). The isolated leukocytes were counted using crystal violet stain. Percentage viability of leukocytes in the buffy coat was determined by Trypan blue dye exclusion.

\section{Isolation of rat peritoneal exudate cells (PEC)}

PECs were isolated from male Wistar rats (adult; 4-weeks-old weighing - 250-300 g) following the standard procedure (31) using Tyrode buffer, pH 7.4 containing 0.1\% BSA. After injecting the peritoneal cavity, the fluid containing PECs was collected and the cells were pelleted, washed with physiological salt solution, and finally resuspended in Tris-CAM buffer. PECs were stained for mast cells using toluidine blue, and their viability was assessed by Trypan blue dye exclusion. The PEC preparation was found to contain 15-20\% mast cells.

\section{Histamine release $(H R)$ assay}

Cells and reagents (BanLec or other proteins) in Tris-CAM buffer were added to polystyrene tubes at a final volume of 1 $\mathrm{mL}$ in an ice bath. Each tube containing $-2 \times 10^{6}$ cells $/ \mathrm{mL}$ was incubated at $37^{\circ} \mathrm{C}$ for $45 \mathrm{~min}$ (30). In each experiment, perchloric acid (final concentration: $3 \%$ ) was added to one set of samples (alternatively, one set of samples was boiled at $100{ }^{\circ} \mathrm{C}$ for $10 \mathrm{~min}$ ), to obtain the total histamine content of cells (Pc). Blank tubes containing only cells and buffer were used as controls for non-specific or spontaneous release (Ps), which was generally $<10 \%$. After $45 ß \mathrm{~min}$, the tubes were transferred to an ice bath to stop the reaction and centrifuged at $1600 \mathrm{rpm}$ at $4{ }^{\circ} \mathrm{C}$ for $20 \mathrm{~min}$; the supernatants were assayed for histamine content $(\mathrm{Pt})$.

The released histamine was quantitated by a fluorometric assay (32). Briefly, the histamine in the supernatant was extracted initially into $n$-butanol, and then $\mathrm{HCl}$; the histamine extracted into $\mathrm{HCl}$ was neutralized, derivatized using OPT, and the reaction arrested using phosphoric acid. The fluorescence intensity of the derivatized histamine was measured using a spectrofluorometer $\left(\lambda_{\mathrm{ex}}=360 \mathrm{~nm} ; \lambda_{\mathrm{em}}=450 \mathrm{~nm}\right)$. The formula for the calculation of percent $\operatorname{HR}(\mathrm{A} \%)$ is $=(\mathrm{Pt}-\mathrm{Ps})$ / $(\mathrm{Pc}-\mathrm{Ps}) \times 100$, where Pt refers to test release, Ps refers to spontaneous release, and Pc refers to complete release.

\section{Statistical analysis}

Each datum represents the arithmetic mean and standard deviation (s.d.) of the different experiments under identical conditions. Student's t-test was used to make a statistical comparison between the paired and unpaired groups. The correlation between histamine release and serum IgE was analyzed to find the correlation coefficient. A p-value of $<0.05$ was considered statistically significant. All the statistical analyses were performed using software SPSS, version 10 (SPSS Inc., Chicago, IL, U.S.).

\section{Results}

\section{Purified banana lectin exhibits hemagglutination activity}

Banana lectin was isolated from banana pulp by affinity chromatography on Sephadex G-75. The column-bound proteins were eluted with elution buffer containing $0.5 \mathrm{M}$ D-glucose. The elution profile is shown in figure 1. Fraction numbers 35-58 were pooled, and analyzed by SDS-PAGE (12\%) and hemag-

Figure 1 - Affinity chromatography of BanLec from pectinase-treated banana pulp on Sephadex G-75 $(2 \times 110 \mathrm{~cm})$. Equilibration and loading buffer: $50 \mathrm{mM}$ sodium acetate buffer, $\mathrm{pH} 4$ containing $0.15 \mathrm{M} \mathrm{NaCl}$. Elution buffer: $50 \mathrm{mM}$ sodium acetate buffer, $\mathrm{pH} 4$ containing $0.15 \mathrm{M} \mathrm{NaCl}$ and $0.5 \mathrm{M} \mathrm{D}$-glucose. Fraction volume: $3 \mathrm{~mL}$. Inset: 12\% SDS-PAGE (reducing); lane 1, purified banana

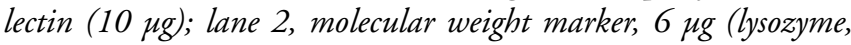
$14.3 \mathrm{kDa}$ ).

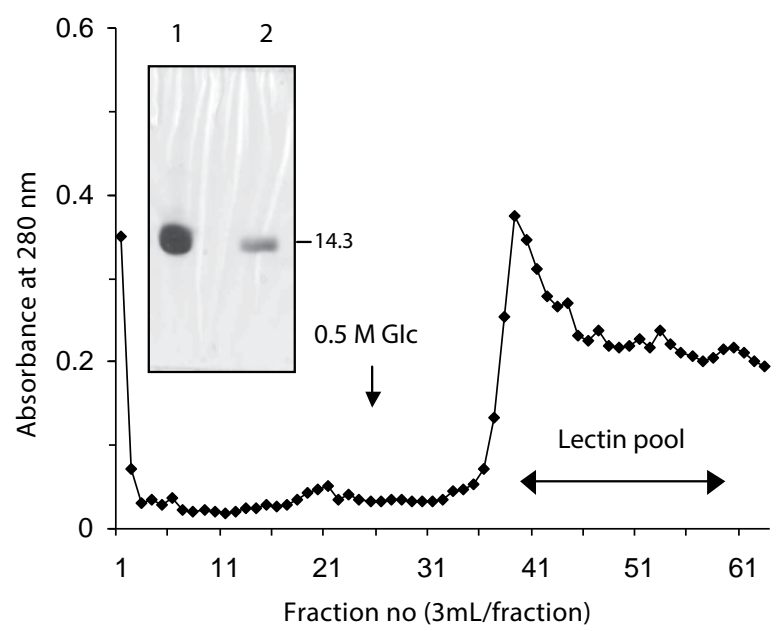


glutination assay. The pooled fraction showed a single band by SDS-PAGE having a molecular mass of $15 \mathrm{kDa}$ (figure 1, inset) and exhibited hemagglutination activity towards $2 \%$ rabbit erythrocytes; the activity was mannose-specific as analyzed by glycoprotein-binding ELISA assay (data not shown). The hemagglutination activity of the pooled fraction was -28.6 units/ $\mathrm{mg}$ protein, wherein one unit of hemagglutination activity is referred to as the minimum amount of protein required for causing hemagglutination activity. The yield of banana lectin from $500 \mathrm{~g}$ of banana pulp was found to be $3.5 \mathrm{mg}$.

\section{SPT of BanLec on atopic subjects indicates a high positivity}

Atopic and non-atopic subjects were selected based on detailed case history and clinical symptoms. The subjects' status of atopic or non-atopic was confirmed in all the subjects under evaluation ( $\mathrm{n}=117$ for atopics, and $\mathrm{n}=20$ for non-atopics) based on SPT. Subjects were considered atopic if they had generalized symptoms characteristic of at least one allergic condition and a positive SPT (> $3 \mathrm{~mm}$ over the negative control) to one of the allergens tested. Subjects were considered non-atopic if they did not have any clinical symptoms suggestive of allergies and had a negative SPT. Consecutive 117 atopic subjects consenting to participate in the study were included; non-atopic subjects were selected from the general population. The results are summarized in table I, which shows the results of SPT with BanLec tested on 117 atopic subjects and on 20 non-atopic subjects. BanLec at $100 \mu \mathrm{g} / \mathrm{mL}$ showed a positive SPT in 33 out of 117 atopic subjects $(28.2 \%)$. It is interesting to note that SPT using banana extract shows that 29 out of 117 atopic subjects (24.8\%) were positive. SPT reactions as assessed by means of wheal/flare diameter were barely positive (designated as $+; 3-3.5 / 5 \mathrm{~mm}$ ) or moderately positive (designated as $2+$; $4-4.5 / 10-15 \mathrm{~mm}$ ) compared to the positive control, histamine base $(6 / 25 \mathrm{~mm})$. None of the non-atopic subjects gave a positive SPT (wheal/flare diameter of $0-1 / 0 \mathrm{~mm}$ ) for both BanLec and banana extract (table I).

Table I - Skin prick testa of banana lectin (BanLec) on human atopic and non-atopic subjects.

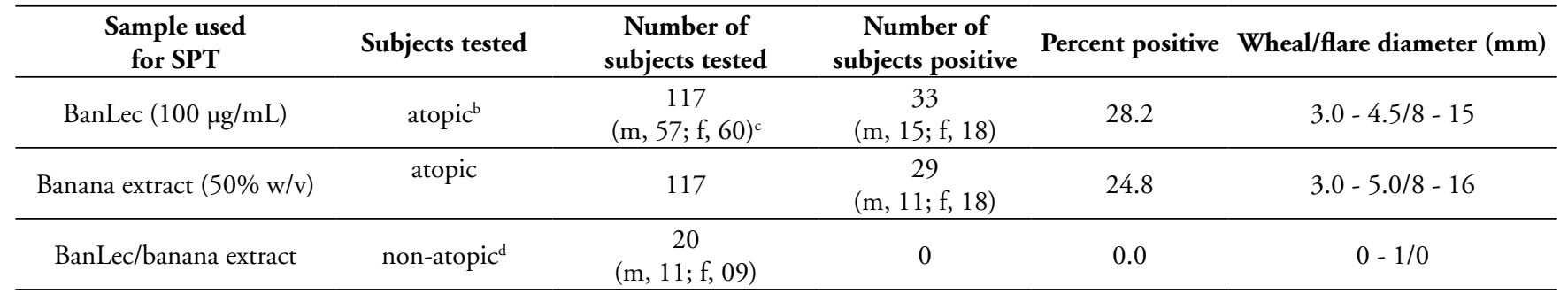

${ }^{\mathrm{a}}$ The positive control used for SPT is glycerinated histamine base $(1 \mathrm{mg} / \mathrm{mL})$, and the negative control is glycerinated PBS.

${ }^{b}$ Subjects displaying characteristic symptoms from any one of the following: asthma, allergic rhinitis, urticaria or food allergy (age range: 18-60 y).

${ }^{c} \mathrm{~m}$, male; f, female.

${ }^{\mathrm{d}}$ Healthy subjects without any clinical symptoms of allergy (age range: 18-60 y).

Table II - Eosinophil counts, serum IgE, and serum/plasma histamine levels in a subset of non-atopiclatopic subjects.

\begin{tabular}{|c|c|c|c|c|c|}
\hline \multirow[b]{2}{*}{ Subjects } & \multirow{2}{*}{$\begin{array}{c}\text { Eosinophil } \\
\text { mean } \pm \text { s.e.m. }(\text { counts } / \mu \mathrm{L})^{\mathrm{a}}\end{array}$} & \multicolumn{2}{|c|}{ Serum IgE } & \multicolumn{2}{|c|}{ Histamine level } \\
\hline & & $\begin{array}{c}\text { mean } \pm \text { s.e.m. } \\
\left(\mathrm{A}_{492}\right)\end{array}$ & $\operatorname{IgE}(\mathrm{IU} / \mathrm{mL})^{\mathrm{b}} \pm$ s.e.m. & $\begin{array}{c}\text { serum } \\
\text { mean } \pm \text { s.e.m. }(\mathrm{ng} / \mathrm{mL})^{\mathrm{c}}\end{array}$ & $\begin{array}{c}\text { plasma } \\
\text { mean } \pm \text { s.e.m. }(\mathrm{ng} / \mathrm{mL})^{\mathrm{d}}\end{array}$ \\
\hline $\begin{array}{c}\text { non-atopic } \\
(\mathrm{n}=10)\end{array}$ & $302 \pm 11$ & $0.267 \pm 0.010$ & $39.3 \pm 4.6$ & $28.2 \pm 3.6$ & $1.5 \pm 1.2$ \\
\hline $\begin{array}{c}\text { atopic } \\
(\mathrm{n}=20)\end{array}$ & $776 \pm 18$ & $1.205 \pm 0.120$ & $253.7 \pm 76.4$ & $184.2 \pm 10.1$ & $11.6 \pm 1.0$ \\
\hline
\end{tabular}

${ }^{a}$ Reference normal value for eosinophil counts $=40-400$ cells $/ \mu \mathrm{L}(23) ; \mathrm{p}<0.001(\mathrm{t}=38.2)$;

${ }^{b}$ Reference normal value for serum total $\operatorname{IgE}=<120 \mathrm{IU} / \mathrm{mL}(24) ; \mathrm{p}<0.001(\mathrm{t}=13.40)$;

'Value for non-atopic subjects is $5-27 \mathrm{ng} / \mathrm{mL}(25) ; \mathrm{p}<0.001(\mathrm{t}=15.74)$;

${ }^{d}$ Value for non-atopic subjects is $0.5-2 \mathrm{ng} / \mathrm{mL}(25)$; $\mathrm{p}<0.001(\mathrm{t}=10.64)$. 
In a subset of 20 atopic and 10 non-atopic subjects, eosinophil counts, serum IgE and serum/plasma histamine levels were measured. The results are shown in table II. The serum total $\operatorname{IgE}$ was found to be significantly higher in atopic subjects, and represents approximately a 5 to 7 -fold increase over the value for non-atopic subjects. In atopic subjects, the eosinophil counts were increased by -2.6 -fold over the mean value of non-atopic subjects $(302$ cells $/ \mu \mathrm{L})$. The serum and plasma histamine levels were found to be significantly higher in atopic subjects ( -6 to 8-fold) as compared to the mean value for non-atopics.

Based on the clinical symptoms, the atopic subjects were subgrouped as representing allergic rhinitis, asthma, or both; this is summarized in table III. Again, in the sub-groups the sensitiv- ity for BanLec was maximal in the sub-group who had clinical symptoms of both allergic rhinitis and asthma, compared to the sub-groups with only allergic rhinitis or asthma. The number of subjects who avoid eating banana was found to be 60 out of $117(51.3 \%)$; these subjects reported that they avoided eating banana as they had experienced an increase in their allergic symptoms upon consumption of banana on most occasions. However, some of them have no SPT reactivity to either banana extract or to BanLec. On the other hand, none of the non-atopic subjects reported the avoidance of banana consumption. About half of the atopic subjects tested in each sub-group were having case history positive to banana, and they were found to avoid banana consumption.

Table III - Results of SPT to BanLec in atopic subjects sharacterized into three subgroups as allergic rhinitis, asthma, and allergic rhinitis with asthma.

\begin{tabular}{|c|c|c|c|c|c|c|}
\hline Subjects' status & $\begin{array}{c}\text { Subjects } \\
\text { positive to BanLec }^{b}\end{array}$ & $\begin{array}{l}\text { Percent } \\
\text { positive }\end{array}$ & $\begin{array}{l}\text { Subjects positive } \\
\text { to banana extract }\end{array}$ & $\begin{array}{l}\text { Percent } \\
\text { positive }\end{array}$ & $\begin{array}{l}\text { Avoidance to banana } \\
\text { (n) }\end{array}$ & $\begin{array}{c}\text { Avoidance to } \\
\text { banana (\%) }\end{array}$ \\
\hline $\begin{array}{l}\text { allergic rhinitis } \\
\quad(\mathrm{n}=33)\end{array}$ & $07(\mathrm{~m} \mathrm{3}, \mathrm{f} 4)^{\mathrm{e}}$ & 21.2 & $11(\mathrm{~m} \mathrm{4}, \mathrm{f} 7)$ & 33.3 & $15(\mathrm{~m} \mathrm{6}, \mathrm{f} 9)$ & 45.5 \\
\hline $\begin{array}{l}\text { allergic rhinitis } \\
\text { with asthma } \\
(\mathrm{n}=45)\end{array}$ & $16(\mathrm{~m} 7, \mathrm{f} 9)$ & 35.5 & $09(\mathrm{~m} \mathrm{3}, \mathrm{f} 6)$ & 20.0 & $25(\mathrm{~m} \mathrm{14}, \mathrm{f} 11)$ & 55.6 \\
\hline
\end{tabular}

${ }^{\text {aAtopic subjects were selected for SPT based on their case history and SPT results to allergenic extracts including house dust mite, and classified into subgroups }}$ based on their clinical symptoms;

${ }^{\mathrm{b} A t o p i c}$ subjects who showed skin prick test positive (> $3 \mathrm{~mm}$ wheal) for BanLec $(100 \mu \mathrm{g} / \mathrm{mL})$;

'Atopic subjects who tested positive for banana extract $(50 \% \mathrm{w} / \mathrm{v})$ by SPT were tested here at $1 \mathrm{mg} / \mathrm{mL}$ banana extract;

${ }^{\mathrm{d}}$ Number of atopic subjects who avoid eating banana and have a positive case history for banana consumption;

${ }^{\mathrm{e}} \mathrm{m}$, male; f, female.

Table IV -Summary of in vivo and in vitro diagnostic tests in the subgroup of atopic subjects positive to BanLec by SPT.

\begin{tabular}{|c|c|c|c|c|c|}
\hline Subjects' status $^{a}$ & $\begin{array}{c}\text { Subjects } \\
\text { positive to } \\
\text { BanLec } \\
\end{array}$ & $\begin{array}{c}\text { Wheal/flare } \\
\text { diameter }(\mathbf{m m})^{\mathrm{b}}\end{array}$ & $\begin{array}{c}\text { Specific IgE } \\
\text { ELISA units }{ }^{c}\left(\mathrm{~A}_{405}\right) \\
\text { mean } \pm \text { s.e.m. }\end{array}$ & $\begin{array}{c}\text { Serum IgE } \\
\text { ELISA units }\left(\mathbf{A}_{492}\right) \\
\text { mean } \pm \text { s.e.m. }\end{array}$ & $\begin{array}{l}\text { Histamine release }^{\mathrm{d}} \\
\text { (\%) (range) }\end{array}$ \\
\hline non-atopic & 00 & $0-1 / 0$ & $0.036 \pm 0.016$ & $0.280 \pm 0.044$ & $23.4-28.9$ \\
\hline $\begin{array}{c}\text { atopic } \\
\text { (mildly sensitive to BanLec) }\end{array}$ & 00 & $1-3 / 0-5$ & $0.049 \pm 0.011$ & $0.466 \pm 0.100$ & $37.8-42.2$ \\
\hline $\begin{array}{c}\text { atopic (moderately sensitive } \\
\text { to BanLec) }\end{array}$ & 23 & $3-4 / 5-10$ & $0.063 \pm 0.023$ & $0.737 \pm 0.155$ & $44.9-56.1$ \\
\hline \multicolumn{6}{|l|}{$\mathrm{a}=10$ in each group; } \\
\hline \multicolumn{6}{|c|}{ 'Positive control, $1 \mathrm{mg} / \mathrm{mL}$ histamine base $(5-6 / 20-25 \mathrm{~mm})$; } \\
\hline \multicolumn{6}{|c|}{$\begin{array}{l}\text { 'Value for non-lectin control (BSA) }(n=6), 0.018 \text { (non-atopic); } 0.020 \text { (atopic); value for lectin control (Con A) }(n=6), 0.056 \text { (non-atopic), } 0.099 \text { (atopic); mean } \\
\text { of } 3 \text { values; }\end{array}$} \\
\hline
\end{tabular}


Atopic subjects show a higher level of serum IgE compared to non-atopic subjects

Serum samples of non-atopic $(\mathrm{n}=10)$ and atopic $(\mathrm{n}=10)$ subjects were tested for the presence of BanLec-specific IgE. Con A (Man/Glc-specific lectin) and BSA (non-lectin protein) were used as negative controls. BanLec-specific IgE values for moderately BanLec-sensitive atopic subjects were very similar to those seen for mildly BanLec-sensitive atopic and non-atopic subjects (table IV). However, the serum IgE level of moderately BanLec-sensitive subjects is -1.5 to 2 -fold higher than that of mildly BanLec-sensitive subjects, and -2 to 3.5 -fold higher than that of non-atopic subjects who are not sensitive to BanLec.

\section{BanLec induces a higher magnitude of $H R$ release from atopics as} compared to non-atopics

The results of percent HR from non-atopic $(n=5)$ and atopic subjects $(\mathrm{n}=7)$ by BanLec in a concentration range of 1 to $5 \mu \mathrm{g} / \mathrm{mL}$ are presented in figure 2 (panel a). Maximal release of histamine occurs at a concentration of $2 \mu \mathrm{g} / \mathrm{mL}$; an increase of about 1.5-fold in HR was observed in the case of atopic subjects $(62.0 \pm 4.7 \%)$ compared to non-atopic subjects $(37.8 \pm 3.7 \%)$. The HR was found to be significant $(\mathrm{p}<0.005)$ at $2 \mu \mathrm{g} / \mathrm{mL}$ concentration.

Con A (positive lectin control) was found to induce HR from both non-atopic and atopic subjects; here again, maximal release was found at $2 \mu \mathrm{g} / \mathrm{mL}$ concentration. The percent $\mathrm{HR}$ was $-40 \%$ in non-atopics (healthy individuals without any symptoms of allergy) and $-73 \%$ in atopic subjects (figure 2, panel b). Both the non-lectin proteins (BSA and ovalbumin) do not release histamine in either non-atopic or atopic subjects; HR using these non-lectin proteins was found to be only $4 \%$ in non-atopics and $6 \%$ in atopics. Generally, the HR is considered negative if the value is $<10 \%$, and the percent $\mathrm{HR}$ as a function of BanLec was comparable with the positive lectin control Con A. Another mannose-specific lectin Favin (from Vicia fava) shows a similar trend as seen for Con A and BanLec, although of a lower magnitude (figure 2, panel b).

The magnitude of HR by BanLec correlates with the serum IgE level

Ten subjects in the non-atopic group and 20 subjects in the atopic group were analyzed for $\mathrm{HR}$ and total IgE levels. The mean value of percent HR as well as the serum total IgE values for both non-atopic and atopic (including its sub-groups) groups are shown in table IV. Since all non-atopic subjects showed serum IgE ELISA unit of $<0.33,0.35$ value was arbitrarily taken as the cut-off point of serum IgE (ELISA unit) for demarcating non-atopics and atopics. On the basis of the serum total IgE level and HR, the atopics can be sub-grouped roughly into three types: (i) mild sensitivity to BanLec with marginal $\mathrm{HR}$, (ii) moderate sensitivity to BanLec with moderate HR, and (iii) high sensitivity to BanLec with high HR. It is seen that all atopic subjects showed a HR of $>35 \%$. Further, the results show that the percent $\mathrm{HR}$ was found to have a fairly good correlation with the serum total IgE levels $\left(\mathrm{R}^{2}=0.817, \mathrm{n}=30\right)$.

Figure 2 - Panel a, comparison of percent histamine release from the leukocytes of non-atopic $(n=5)$ and atopic $(n=7)$ subjects as a function of BanLec concentration (1 to $5 \mu \mathrm{g} / \mathrm{mL}$ ). Panel $\mathbf{b}$, Comparison of histamine release from the leukocytes of atopic $(n=$ 7) and non-atopic $(n=5)$ subjects as a function of BanLec with the lectin control (Con A) and non-lectin controls (non-lectin proteins: BSA and OVA). Protein amount used: $2 \mu \mathrm{g}$ in all cases.

a)

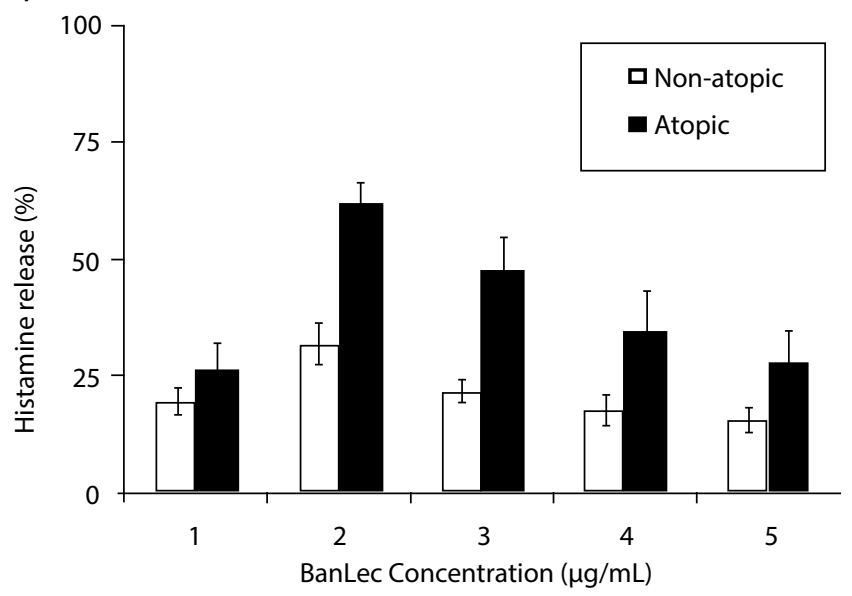

b)

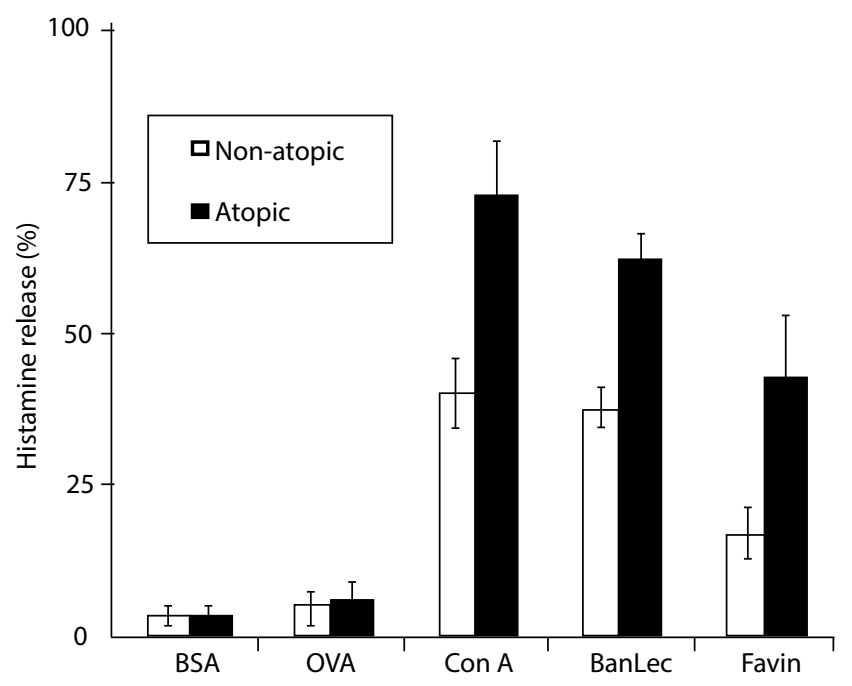


BanLec also induces HR from rat peritoneal exudates cells (PECs)

Con A (Man/Glc-specific lectin), which is taken as a reference lectin showed $-58 \% \mathrm{HR}$ and can be regarded as positive control for HR assay using rat peritoneal exudates cells (figure 3). BSA (data not shown) and ovalbumin (non-lectin proteins) show minimal HR and can, therefore, be considered as negative controls. Favin and BanLec were found to induce the release of histamine (about 4-fold and 6-fold, respectively) in comparison to the HR value of the negative control, OVA.

\section{Discussion}

BanLec shows specificity for molecules containing D-glucopyranosyl, D-mannopyranosyl and other related carbohydrate structures (33-35); it shares many properties with Glc/Man-recognizing legume lectins (Con A). The yield of BanLec was found to be $7 \mathrm{mg} / \mathrm{kg}$ banana pulp; its purity was confirmed by SDSPAGE (single band of $15 \mathrm{kDa}$ ) and hemagglutination activity indicated glucose/mannose specificity.

SPT of BanLec revealed that roughly one fourth of the atopic subjects were positive, whereas non-atopic subjects were negative. A positive SPT of $28.2 \%$ to a purified protein (BanLec) from banana pulp appears to be unusual for food allergy, since the incidence of food allergy in adults is generally $2-4 \%(8,9)$. This may be due to the non-specific interaction of BanLec with

Figure 3 - Histamine release from rat PECs containing mast cells at $2 \mu \mathrm{g}$ protein. Compound $48 / 80$ was used as a positive control for histamine release from mast cells. Con $A$ was used as a lectin control, and BSA and OVA were used as non-lectin controls.

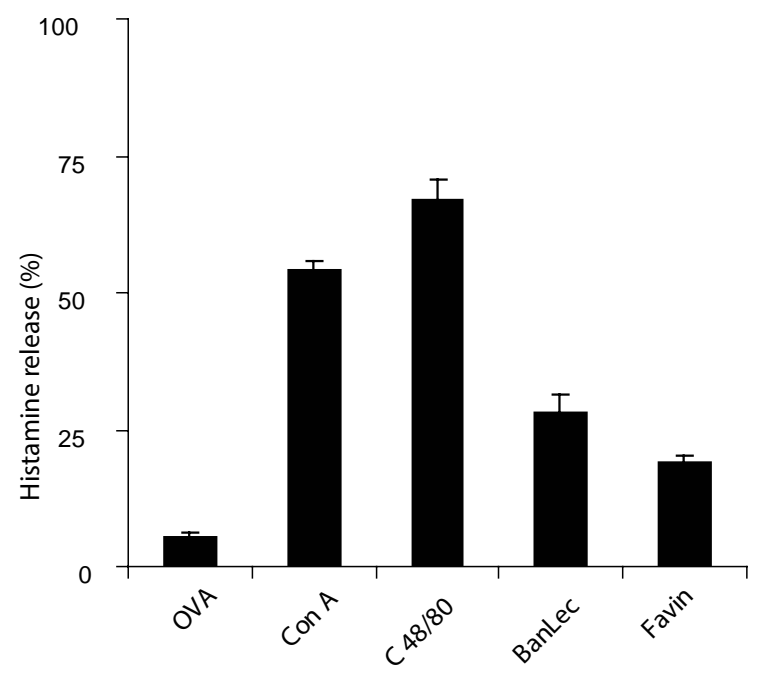

the carbohydrate structures of mast cells in vivo followed by activation. Similar results have been observed from our earlier studies on the effects of potato lectin in SPT of atopic subjects (14). In the case of atopic subjects who showed a positive SPT for BanLec, the serum IgE level was, in general, 3-8-fold higher than in non-atopic subjects. The banana reactors $(24.8 \%$ among atopic patients as assessed by positive SPT) also had BanLec reactivity (28.2\% among atopic patients as seen by positive SPT); however, the reactors did not show any specific IgE to banana protein(s). It is likely that the sensitivity is due to the effect of BanLec both in pure form or as crude form (in banana extract) which causes wheal/flare reaction through non-allergic food hypersensitivity by interacting with non-specific IgE on mast cells or basophils.

Mannose-binding lectins (Con A, Lens culinaris agglutinin, and pea agglutinin) bind strongly to human IgE (5); the binding is mainly attributable to the complex-type glycopeptide of IgE (36). BanLec has specificity for Glc/Man similar to Con A $(18,19)$. Since cell-bound $\operatorname{IgE}$ is a glycoprotein rich in oligosaccharides $(-12 \%)$ in its Fc portion (both oligomannose and complex bi-antennary types), we examined the composition and structures of the N-linked glycans on the heavy chain of $\operatorname{IgE}$ (37). Among the glycans of human IgE, $-86 \%$ of glycans terminate in galactose or sialic acid, which represent complex bi-antennary type glycans (36). Though the serum IgE level was 2 to 8-fold higher in atopic subjects (who are positive to BanLec by SPT) as compared to non-atopics, BanLec-specific IgE was found to be very similar in the serum of both atopic and non-atopic subjects confirming that none of the atopic subjects were truly allergic to BanLec. Although 6 allergens (Mus a 1 to Mus a 6) have been identified as allergens in banana so far, BanLec has not been reported as an allergen in the WHO/IUIS Allergen Nomenclature home page (www.allergen.org). Lectins have been ranked ninth in their assignment as plant food allergen families in Pfam database (38), and are generally regarded as minor allergens.

Koshte et al. (22) observed that $\operatorname{IgG} 4$ antibodies to banana were found to occur far more frequently than expected, and the most important antigen involved proved to be BanLec; the authors firmly established the antigen-antibody nature of the BanLec-IgG4 interactions. Their results support the earlier suggestion that some lectins are particularly prone to induce an immune response upon oral feeding (7). Several studies in the past decade have shown that BanLec is a mucosal immunostimulator, and that oral administration of BanLec modulates cytokine profile and abundance of T-cell populations in mice (39-41). HR from the leukocytes of non-atopic and atopic subjects by BanLec was found to be dependent on serum IgE levels; the release shows a fairly good correlation to serum $\mathrm{IgE}$ levels $\left(\mathrm{R}^{2}\right.$ $=0.8166$ ); such a correlation clearly indicates that the effect of BanLec depends on the basophil IgE density in causing non-spe- 
cific activation. This is strikingly similar to the effect of Con A, wherein the HR is higher than spontaneous release (seen for non-lectin proteins) in non-atopics, and comparatively more so in atopics $(4,6,13)$.

It is interesting to note that a clear correlation between serum $\mathrm{IgE}$ and expression of FceRI on basophils has been established earlier in several allergic conditions (42). Con A-induced HR has been shown to be dependent on the IgE density on basophils $(4,6,8)$; Con $\mathrm{A}$ binds to terminal/internal mannose on $\operatorname{IgE}$ glycans, and cross-links cell-bound non-specific $\operatorname{IgE}(4,13,42)$ leading to degranulation. Dam et al. (43) showed that a significant correlation exists between the histamine-releasing properties of Diocleinae lectins (Glc/Man specificity) and their relative affinity constants for biantennary complex carbohydrates.

Figure 4 - Structure of complex bi-antennary type N-glycan of $\operatorname{IgE}(3,36)$ showing the binding site for BanLec (specificity for mannose shown as Man (shown in a small box), and for trimannoside core (shown in a large box)); the specificity for Man and trimannoside core is similar to that of concanavalin A (Con A). Solanum tuberosum agglutinin (potato lectin or STA) has specificity for GlcNAc oligomers (14), and the core chitobiose unit is indicated by an arrow. Aspergillus oryzae lectin (AOL) has specificity for a1,6-fucosyl residue (44) which is generally referred to as the "core fucose" in complex $N$-glycans, and this is also indicated by an arrow. One of the two branches of the IgE glycans may or may not contain sialic acid.

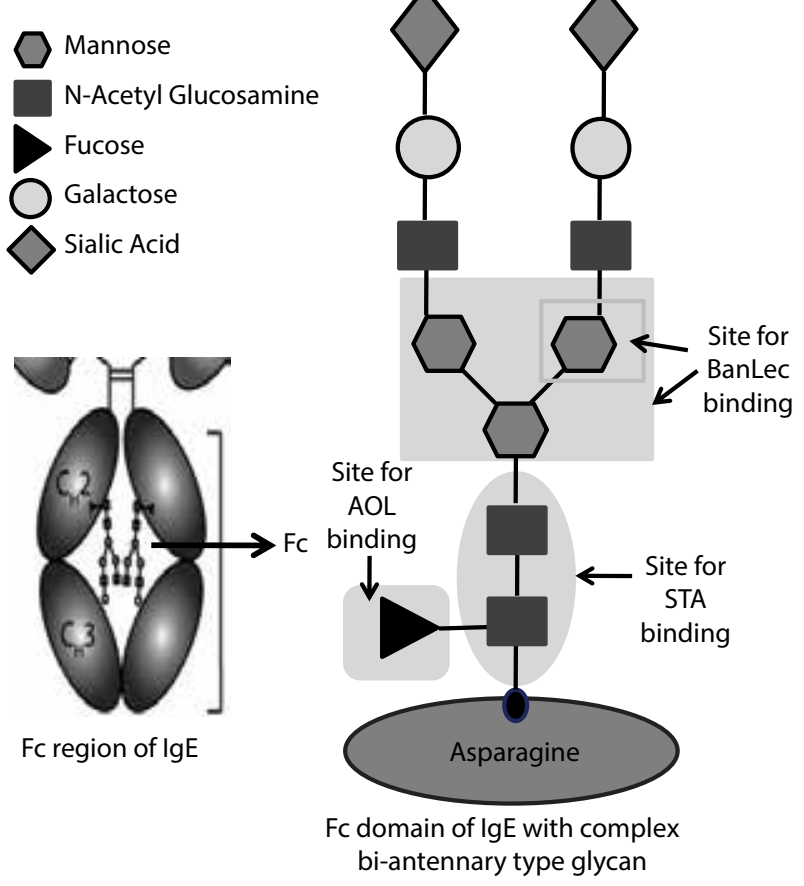

Non-specific degranulation of mast cells/basophils has also been demonstrated by the interaction of potato lectin (specific for core chitobiose) and Aspergillus oryzae lectin (specific for $\alpha 1,6$-fucosyl residue or "core fucose") of non-specific IgE $(14,44)$. The binding sites of potato lectin, Aspergillus oryzae lectin and BanLec to the respective sugars on the complex bi-antennary type $N$-glycans of $\operatorname{IgE}$ are represented summarily in figure 4 .

In addition to binding to the trimannoside core of $\mathrm{IgE}$ glycans, one may speculate that BanLec can also bind to the mannose residues of the $N$-glycans of $\alpha$-chain of human FceRI, the high-affinity IgE receptor on mast cells/basophils (8-10); the extracellular domain of $\alpha$-chain is heavily glycosylated (38-42\% $N$-linked, and $4 \% O$-linked glycans of $\alpha$-chain molecular mass) (45). The expression of FcERI is dependent on serum IgE; since the receptor number is certainly higher in the case of atopics (42), BanLec can potentially cross-link free cell-surface Fc\&RI through the $\alpha$-chain, and cause activation.

\section{Conclusions}

SPT using $100 \mu \mathrm{g} / \mathrm{mL}$ BanLec was positive in $28.2 \%$ of atopic subjects although there was no evidence of type I allergy to BanLec as shown by the absence of BanLec-specific serum IgE. HR from the leukocytes of non-atopic and atopic subjects by BanLec was found to show a moderately good correlation to serum IgE levels $\left(R^{2}=0.817\right)$. Based on the results of HR from rat PECs, leukocytes of atopics, and positive SPT to BanLec in a majority of atopic population, it can be concluded that the binding of BanLec to basophils and mast cells is primarily through its interaction with the trimannoside core of $N$-glycans of cell-bound non-specific IgE; on the contrary, non-atopic subjects show only marginal activation and degranulation of mast cells/basophils. This may explain why several atopic subjects (suffering from allergic rhinitis, asthma, or both) experience adverse reactions upon consumption of banana fruit and therefore avoid eating banana, although they are not truly allergic to banana fruit.

\section{Acknowledgements}

This work was funded by the Science and Engineering Research Council of Department of Science and Technology (DST), New Delhi, India, grant-in-aid project no. SP/SO/B69/98 (YPV). The invaluable assistance of professor Anjali A. Karande (Department of Biochemistry, Indian Institute of Science, Bengaluru, India) in providing hybridoma cell culture supernatant of murine monoclonal anti-human IgE is gratefully acknowledged.

\section{Conflicts of interest}

The authors declare that they have no conflicts of interest. 


\section{References}

1. André S, Kaltner H, Manning JC, Murphy PV, Gabius HJ. Lectins: getting familiar with translators of the sugar code. Molecules 2015; 20(2):1788-1823.

2. Van Damme EJ. History of plant lectin research, Methods Mol Biol 2014; 1200:3-13.

3. Taylor ME, Drickamer K. Introduction to Glycobiology. Oxford University Press, Oxford, 2003.

4. Magro AM. Involvement of IgE in con A-induced histamine release from human basophils in vitro. Nature 1974; 249(457):572-573.

5. Shibasaki M, Sumazaki R, Isoyama $S$, Takita $H$. Interactions of lectins with human IgE: IgE-binding property and histamine-releasing activity of twelve plant lectins. Int Arch Allergy Immunol 1992; 98(1):18-25.

6. Siraganian PA, Siraganian RP. Basophil activation by concanavalin A: characteristics of the reaction. J Immunol 1974; 112(6):2117-2125.

7. Kjaer TMR, Frokiaer H. Dietary lectins and the immune response. Rev Food Nutr Toxicity 2005; 4:271-295.

8. Schwartz C, Eberle JU, Voehringer D. Basophils in inflammation. Eur J Pharmacol 2016; 778:90-95.

9. Stone KD, Prussin C, Metcalfe DD. IgE, mast cells, basophils, and eosinophils. J Allergy Clin Immunol 2010; 125(2 Suppl 2):S73-80.

10. Helm RM, Froese A. Binding of the receptors for $\operatorname{IgE}$ by various lectins. Int Arch Allergy Appl Immunol 1981; 65(1):81-84.

11. Haas H, Falcone FH, Schramm G, Haisch K, Gibbs BF, Klaucke J, Pöppelmann M, Becker WM, Gabius HJ, Schlaak M. Dietary lectins can induce in vitro release of IL-4 and IL-13 from human basophils. Eur J Immunol 1999; 29(3):918-927.

12. Moreno AN, Jamur MC, Oliver C, Roque-Barreira MC. Mast cell degranulation induced by lectins: effect on neutrophil recruitment. Int Arch Allergy Immunol 2003; 132(3):221-230.

13. Busse WW, Swenson CA, Sharpe G, Koschat M. Enhanced basophil histamine-release to concanavalin A in allergic rhinitis. J Allergy Clin Immunol 1986; 78(1Pt 1):90-7.

14. Pramod SN, Venkatesh YP, Mahesh PA. Potato lectin activates basophils and mast cells of atopic subjects by its interaction with core chitobiose of cell-bound non-specific immunoglobulin E. Clin Exp Immunol 2007; 148(3):391-401.

15. Mathew NS, Negi PS. Traditional uses, phytochemistry and pharmacology of wild banana (Musa acuminata Colla): a review. J Ethnopharmacol 2017; 196:124-140.

16. Koshte VL, van Dijk W, van der Stelt ME, Aalberse RC. Isolation and characterization of BanLec-I, a mannoside-binding lectin from Musa paradisiac (banana). Biochem J 1990; 272(3):721-726.

17. Peumans WJ, Zhang W, Barre A, Houlès-Astoul C, Balint-Kurti PJ, Rovira P, Rougé P, May GD, Van Leuven F, Truffa-Bachi P, Van Damme EJ. Fruit-specific lectins from banana and plantain. Planta 2000; 211(4):546-554.

18. Mo H, Winter HC, van Damme EJM, Peumans WJ, Misaki A, Goldstein IJ. Carbohydrate-binding properties of banana (Musa acuminata) lectin. I. Novel recognition of internal $\alpha 1,3$-linked glucosyl residues. Eur J Biochem 2001; 268(9):2609-2615.

19. Goldstein IJ, Winter HC, Mo H, Misaki A, Van Damme EJM, Peumans WJ. Carbohydrate-binding properties of the banana (Musa acuminata) lectin. II. Binding of laminaribiose oligosaccharides and $\beta$-glucans containing $\beta 1,6$-linked glucosyl end groups. Eur J Biochem 2001; 268(9):2616-2619.
20. Singh DD, Saikrishnan K, Kumar P, Dauter Z, Sekar K, Surolia A, Vijayan M. Purification, crystallization and preliminary X-ray structure analysis of the banana lectin from Musa paradisiaca. Acta Crystallogr D Biol Crystallogr 2004; 60(Pt 11):2104-2106.

21. Meagher JL, Winter HC, Ezell P, Goldstein IJ, Stuckey JA. Crystal structure of banana lectin reveals a novel second sugar binding site. Glycobiology 2005; 15(10):1033-1042.

22. Koshte VL, Aalbers M, Calkhoven PG, Aalberse RC. The potent IgG4-inducing antigen in banana is a mannose-binding lectin, BanLec-I. Int Arch Allergy Immunol 1992; 97(1):17-24.

23. Ying S, Meng Q, Smith SJ, Larché M, Robinson DS, Kay AB. Methods for identifying human eosinophils in blood and tissue. ACI Int 2002; 14(2):64-71.

24. Hamilton RG, Adkinson NF Jr. Clinical laboratory assessment of IgE-dependent hypersensitivity. J Allergy Clin Immunol 2003(2 Suppl); 111:S687-701.

25. Oguri S, Yoneya Y. Assay and biological relevance of endogenous histamine and its metabolites: application of microseparation techniques. J Chromatogr B Analyt Technol Biomed Life Sci 2002; 781(1-2):165-179.

26. Laemmli UK. Cleavage of structural proteins during the assembly of the head of bacteriophage T4. Nature 1970; 227(5259):680-685.

27. Burger MM. Assays for agglutination with lectins. Methods Enzymol 1974; 32:615-621.

28. Bradford MM. A rapid and sensitive method for the quantitation of microgram quantities of protein utilizing the principle of protein-dye binding. Anal Biochem 1976; 72(1-2):248-254.

29. Sanico AM, Bochner BS, Saini SS. Skin testing methods. In: Adelman DC, Casale TB, Corren J (Eds.). Manual of Allergy and Immunology, $4^{\text {th }}$ edn, Lippincott Williams and Wilkins, Philadelphia, 2002:485-486.

30. Kampen GT, Poulsen LK, Reimert CM, Skov PS. A method for production and determination of histamine releasing activity from human peripheral blood mononuclear cells. J Immunol Methods 1997; 210(2):185-193.

31. Sullivan TJ, Greene WC, Parker CW. Concanavalin A-induced histamine release from normal rat mast cells. J Immunol 1975; 115(1):278-282.

32. Siegel PD, Lewis DM, Petersen M, Olenchock SA. Observations on the use of $o$-phthalaldehyde condensation for the measurement of histamine. Analyst 1990; 115(8):1029-1032.

33. Singh DD, Saikrishnan K, Kumar P, Surolia A, Sekar K, Vijayan M. Unusual sugar specificity of banana lectin from Musa paradisia$c a$ and its probable evolutionary origin. Crystallographic and modelling studies. Glycobiology 2005; 15(10):1025-1032.

34. Winter HC, Oscarson S, Slättegård R, Tian M, Goldstein IJ. Banana lectin is unique in its recognition of the reducing unit of 3-O-beta-glucosyl/mannosyl disaccharides: a calorimetric study. Glycobiology 2005; 15(10):1043-1050.

35. Singh SS, Devi SK, Ng TB. Banana lectin: a brief review. Molecules 2014; 19(11):18817-18827.

36. Baenziger J, Kornfeld S, Kochwa S. Structure of the carbohydrate units of IgE immunoglobulin. II. Sequence of the sialic acid-containing glycopeptides. J Biol Chem 1974; 249(6):1897-1903.

37. Arnold JN, Radcliffe CM, Wormald MR, Royle L, Harvey DJ, Crispin M, Dwek RA, Sim RB, Rudd PM. The glycosylation of human serum $\operatorname{IgD}$ and $\operatorname{IgE}$ and the accessibility of identified oligomannose structures for interaction with mannan-binding lectin. J Immunol 2004; 173(11):6831-6840. 
38. Jenkins JA, Griffiths-Jones S, Shewry PR, Breiteneder H, Mills ENC. Structural relatedness of plant food allergens with specific reference to cross-reactive allergens: an in silico analysis. J Allergy Clin Immunol 2005; 115(1):163-170.

39. Gavrovic-Jankulovic M, Poulsen K, Brckalo T, Bobic S, Lindner B, Petersen A. A novel recombinantly produced banana lectin isoform is a valuable tool for glycoproteomics and a potent modulator of the proliferation response in $\mathrm{CD} 3+, \mathrm{CD} 4+$, and CD8+ populations of human PBMCs. Int J Biochem Cell Biol 2008; 40(5):929-941.

40. Dimitrijevic R, Stojanovic M, Micic M, Dimitrijevic Lj, Gavrovic-Jankulovic M. Recombinant banana lectin as mucosal immunostimulator. J Funct Foods 2012; 4(3):636-641.

41. Sansone AC, Sansone M, Dos Santos Dias CT, Oliveira do Nascimento JR. Oral administration of banana lectin modulates cytokine profile and abundance of T-cell populations in mice. Int J Biol Macromol 2016; 89:19-24.
42. Saini SS, Klion AD, Holland SM, Hamilton RG, Bochner BS, MacGlashan DW Jr. The relationship between serum IgE and surface levels of FceR on human leukocytes in various diseases: correlation of expression of FceRI on basophils but not on monocytes or eosinophils. J Allergy Clin Immunol 2000; 106(3):514-520.

43. Dam TK, Cavada BS, Grangeiro TB, Santos CF, de Sousa FA, Oscarson S, Brewer CF. Diocleinae lectins are a group of proteins with conserved binding sites for the core trimannoside of asparagine-linked oligosaccharides and differential specificities for complex carbohydrates. J Biol Chem 1998; 273(20):12082-12088.

44. Yamaki K, Yoshino S. Aspergillus oryzae lectin induces anaphylactoid oedema and mast cell activation through its interaction with fucose of mast cell-bound non-specific IgE. Scand J Immunol 2011; 74(5):445-453.

45. Letourneur O, Sechi S, Willette-Brown J, Robertson MW, Kinet JP. Glycosylation of human truncated FceRI $\alpha$ chain is necessary for efficient folding in the endoplasmic reticulum. J Biol Chem $1995 ; 270(14): 8249-8256$. 